DOI https://doi.org/10.30525/978-9934-26-180-0-42

\title{
ОСОБЛИВОСТІ ІНШОМОВНОГО МІЖКУЛЬТУРНОГО СПІЛКУВАННЯ
}

\author{
Кодлюк Л. I. \\ аспірантка I курсу \\ Тернопільський національний педагогічний університет \\ імені Володимира Гнатюка \\ м. Тернопіль, Украӥна
}

Активізація інтернаціонального співробітництва та міжнародна мобільність актуалізують питання володіння іноземною мовою (IM) як важливим засобом міжкультурного спілкування. Це своєрідний інструмент пізнання іншої культури і популяризації власної, що сприяє духовному взаємозбагаченню народів.

Слід відмітити, що спілкування $є$ як міжмовним, так і міжкультурним явищем. Комуніканти мають засвоїти не лише певний лексичний запас та згідно з граматичними правилами формулювати свої думки IM в усній чи письмовій формі, а й оперувати мінімумом знань про рідну і чужу культури, дотримуватися уставлених норм і правил поведінки, тобто володіти структурними компонентами іншомовної комунікативної компетентності (ІКК) - мовною, мовленнєвою, лінгвосоціокультурною.

Недостатній рівень сформованості лінгвосоціокультурної компетентності (ЛСК) може стати бар'єром до здійснення успішної іншомовної комунікації (міжособистісної чи професійної), спричинити неприйнятність або негативне ставлення до чужого стилю життя, призвести до непорозуміння представників різних націй тощо.

Зазначене вище актуалізує дослідження особливостей міжкультурного спілкування як важливого процесу, що інтегрує два складники - мову та культуру.

Аналіз наявного наукового фонду свідчить про те, що заявлена проблема займає чільне місце у вітчизняній та зарубіжній науці. Так, наприклад, особливості формування ІКК досліджували Н. Гез, I. Задорожна, С. Ніколаєва, В. Редько, А. Щукін, М. Кенел, Ян Ван Ек, С. Савіньйон, та ін.; до проблеми формування ЛСК звертались такі науковці: С. Верещагін, І. Зимня, В. Костомаров, О. Соловова та ін.; місце ІМ в контексті діалогу культур вивчали Ю. Пассов та В. Сафонова; питання навчання усного спілкування розглядалося О. Бігич, Г., Н. Скляренко, В. Черниш та ін. 
Мета нашого дослідження полягає в обгрунтуванні особливостей іншомовного міжкультурного спілкування.

Здійснення повноцінної міжкультурної взаємодії з представниками інших країн можливе за умови формування у процесі навчання IM важливого складника ІКК - ЛСК, яка охоплює соціолінгвістичну, соціокультурну та соціальну компетентності.

Науковці дефініціють означений феномен як знання та вміння використовувати у мовленнєвому акті й пізнанні іншомовні соціокультурні та соціолінгвістичні реалії [6, с. 22]. Методисти розглядають ЛСК як здатність і готовність особистості до іншомовного міжкультурного спілкування (опосередкованого чи безпосереднього) [4, с. 425-432]. Сформованість відповідних знань, навичок та вмінь цієї багатокомпонентної структури, згідно із твердженнями учених, є показником здатності й готовності до: контактів 3 носіями мови; усвідомлення нерозривних зав'язків між категоріями «мова» і «культура»; врахування при комунікації особливостей рідної культури та її зіставлення із чужою; формування емпатії, толерантності та неупередженості.

Учені стверджують, що володіння ЛСК дає змогу останній вийти за межі рідної культури й набути якостей медіатора чужої, не втрачаючи водночас власної національної ідентичності [7, с. 40]. Такий підхід О. Соловова вважає передумовою здійснення «діалогу культур». Дослідниця акцентує увагу на тому, що цей процес інтегрує знання про власну та іноземну культури, враховує здатність оперувати ними у мовленнєвому акті [10, с. 12]. Тотожним є твердження I. Бім. Науковець також підкреслює важливість знань про культуру країни, мова якої вивчається, адже вони сприяють кращому усвідомленню рідної, а також удосконаленню уміння представляти іiі у процесі комунікації [3, с. 159-160].

У Загальноєвропейських рекомендаціях 3 мовної освіти зазначається, що «знання спільних цінностей та ідеалів, прийнятих соціальними групами в інших країнах або регіонах (як, наприклад, релігійні вірування, табу, що виникли у ході спільної історії, і т. ін.), є найсуттєвішими для міжкультурного спілкування» [8, с. 11].

Основоположними 3 питань міжкультурної комунікації стали праці зарубіжних учених Е. Холла та Г. Трейгера [12]. Дослідники тлумачать це явище як процес ефективної адаптації людини до навколишнього середовища. У напрацюваннях Є. Верещагіна та В. Костомарова міжкультурна комунікація позиціонується як адекватне взаєморозуміння двох учасників комунікативного акту, що приналежні до різних культурномовних спільнот [5]. 
Сучасне розуміння міжкультурної комунікації - це спілкування партнерів (вербальне і невербальне), які належать до певних національних культур. Увага акцентується на тому, що у цьому процесі стикаються різні концептуальні та мовні картини світу, образи життя, національні характери, ціннісні орієнтації, моделі і норми поведінки тощо. Здійснення міжкультурного спілкування забезпечує досягнення взаєморозуміння шляхом координування своєї і чужої перспектив [4, с. 418].

Для визначення особливостей міжкультурної комунікації учені виходять із категорій «культура» і «спілкування». Так, наприклад, С. ТерМінасова вважає, що для забезпечення ефективної комунікації між представниками різних культур потрібно подолати не лише мовний бар'єр, а й культурний [11, с. 8-10].

Отже, в цілому неможливо оволодіти мовою без розуміння та сприймання культури: перша є необхідною передумовою до розуміння другої і визначає характер іiї розвитку.

Спілкування ж у широкому значенні цього поняття $\epsilon$ сукупністю зав'язків і взаємодії між людьми, суспільствами, суб'єктами (класами, групами, особистостями), у яких відбувається обмін інформацією, досвідом, уміннями, навичками, результатами діяльності, взаємовпливами і корекцією поведінки тощо [2, с. 162]. За твердженнями науковців, спілкування не може обмежуватися лише комунікативною функцією, а має передбачати активну взаємодію учасників цього процесу, мета якого дуже часто має «немовний» характер [9, с. 22].

Поглиблюють розуміння особливостей іншомовного міжкультурного спілкування дослідження психологів. 3 психологічної точки зору учені розглядають міжкультурне спілкування [1] як єдність трьох аспектів: комунікативного (міжкультурне спілкування як обмін інформацією), інтерактивного (міжкультурне спілкування як взаємодія) та перцептивного (міжкультурне спілкування як розуміння людини людиною).

Таким чином, ефективність міжкультурного спілкування як взаєморозуміння представників різних соціумів з їх численними розбіжностями та відмінностями забезпечується сформованістю усіх складників ІКК. Особливість цього типу комунікації полягає у тому, що процес мовного контакту інтегрується з рідною та чужою культурами, що актуалізує оволодіння ЛСК. 3 іншого боку, досвід міжкультурного спілкування сприяє мовній досконалості особистості, а також є безцінним джерелом пізнання світобачення іншої країни.

Перспективи подальших досліджень вбачаємо у з'ясуванні сутності ЛСК як структурного компонента ІКК. 


\section{Література:}

1. Андреева Г.М. Социальная психология. Учебник для высших учебных заведении. М.: Аспект Пресс, 2001. 290 с.

2. Бацевич Ф.С. Словник термінів міжкультурної комунікації. К. : Довіра, 2007. 205 с

3. Бим И. Л. Компетентностный подход к образованию и обучению иностранным языкам / Компетенции в образовании: опыт проектирования. М.: Научно-внедренческое предприятие «ИНЭК», 2007. 327 с.

4. Бігич О. Б., Бориско Н. Ф., Борецька Г. Е. та ін. / за заг. ред. С. Ю. Ніколаєвої. Методика навчання іноземних мов і культур: теорія і практика. К. : Ленвіт, 2013. 590

5. Верещагин Е. М., Костомаров В. Г. Язык и культура: Лингвострановедение в преподавании русского языка как иностранного. М.: Русский язык, 1990. 246 с.

6. Воробйова, І. А. Основи лінгвокраїнознавства. Київ : Слово, 2014. $269 \mathrm{c}$.

7. Дука М. В. Поняття «лінгвосоціокультурна компетентність» та аналіз методів іiі формування в педагогічній теорії і практиці. Педагогічні науки: теорія, історія, інноваційні технології. Суми : СумДПУ ім. А. С. Макаренка, 2015. № 7 (51). С. 39-48.

8. Загальноєвропейські Рекомендації 3 мовної освіти: вивчення, викладання, оцінювання / наук. ред. укр. видання д-р пед. наук, проф. С. Ю. Ніколаєва. К. : Ленвіт, 2003. 273 с.

9. Редько В. Г. Засоби формування комунікативної компетентності у змісті шкільних підручників 3 іноземних мов. Теорія і практика : монографія. К. : Генеза, 2012. 224 с.

10. Соловова Е. Н. Методика обучения иностранным языкам: базовый курс : пособие для студентов пед.вузов и учителей. М. : АСТ: Астрель, 2009. 238 с.

11. Тер-Минасова С. Г. Война и мир языков и культур. М. : Слово/Slovo, 2008. 344 c.

12. Hall E., Hall M. Hidden Differences. Studies in International Communication. How to communicate with Germans. Hamburg, 1983. 